Saint Louis University School of Law

Scholarship Commons

All Faculty Scholarship

2013

\title{
The Corporate Income Tax: United States of America Report
}

Henry Ordower

Saint Louis University School of Law

Follow this and additional works at: https://scholarship.law.slu.edu/faculty

Part of the Taxation-Federal Commons, and the Tax Law Commons

\section{Recommended Citation}

Ordower, Henry, The Corporate Income Tax: United States of America Report (2012). Meeting of the European Association of Tax Law Professors, Lisbon, Portugal, May, 2013.

This Conference Proceeding is brought to you for free and open access by Scholarship Commons. It has been accepted for inclusion in All Faculty Scholarship by an authorized administrator of Scholarship Commons. For more information, please contact erika.cohn@slu.edu,

ingah.daviscrawford@slu.edu. 
The Corporate Income Tax: United States of America Report

Prepared for the 2013 Meeting of the European Association of Tax Law Professors

Lisbon, Portugal, May, 2013

\author{
By \\ Henry Ordower \\ Professor of Law \\ Saint Louis University School of Law
}

Overview. While legislation is the primary determinant of income tax law in the United States, ${ }^{1}$ both the United States Department of the Treasury (Treasury) ${ }^{2}$ and the federal courts ${ }^{3}$ interpret, establish, expand and contract tax rules with binding effect. Like all administrative agencies, Treasury has the power to promulgate interpretive regulations, ${ }^{4}$ and whenever a statute authorizes Treasury to do so, Treasury also may promulgate legislative regulations that determine the tax rules with respect to specific congressionally authorized subject matter. ${ }^{5}$ In the absence of controlling statutes and regulations, judicial decisions may establish, not just interpret, taxation rules in order to resolve a controversy between a taxpayer and the government. Because the United States is a common law jurisdiction, the applicability of a judicial decision extends beyond the immediate controversy and forms part of the body of precedent to which the government and taxpayers must look in order to ascertain the tax law. ${ }^{6}$ Decisions of the United States Supreme Court in tax matters govern absolutely in tax matters.

\footnotetext{
${ }^{1}$ The Internal Revenue Code of 1986, as amended (the Code), title 26 of the United States Code, assembles the tax laws of the U.S. applicable to both individuals and entities. This report refers to specific provisions of the Code either as "section" (followed by a number) "of the Code" or as "I.R.C. §" followed by a number.

${ }^{2}$ The Internal Revenue Service (IRS) is the tax agency under the Department of the Treasury. Treasury through the IRS promulgates regulations in compliance with the Administrative Procedures Act, 5 USC $\$ 551$ et seq. (the APA).

${ }^{3}$ In tax matters, the federal courts consist of those courts under Article III of the U.S. Constitution, the judges of which have life tenure, including the federal district courts, courts of appeals and the Supreme Court, and other courts the judges of which do not have life tenure, including the Tax Court and the Claims Court, the latter being the tribunal established for monetary claims against the U.S. Procedurally, the taxpayer initiates court proceedings (other than criminal prosecutions and collections) and has the initial burden of proof. See, generally, Henry Ordower, United States Report in BURDEN OF PROOF (EATLP Annual Congress Uppsala 2011) (forthcoming). To initiate lawsuit in a district court or the Claims Court against the government in a tax matter, the taxpayer first must pay the tax. The taxpayer may petition the Tax Court for redetermination of a tax deficiency without first paying the tax. In the district courts, but not the Tax Court or Claims Court, the taxpayer has the right to trial by jury. ${ }^{4}$ I.R.C. $\$ 7805$ (a) (granting the Secretary [of the Treasury] the power to promulgate necessary regulations).

5 USC $\$ 553$ (providing rule making procedures under the APA). Congress uses a variety of formulations to delegate legislative rulemaking authority to Treasury, for example, I.R.C. $§ 357(d)(3)$ reads as follows:

"Regulations. The Secretary shall prescribe such regulations as may be necessary to carry out the purposes of this subsection and section 362(d) [26 USCS $\$ 362(d)$ ]. The Secretary may also prescribe regulations which provide that the manner in which a liability is treated as assumed under this subsection is applied, where appropriate, elsewhere in this title."

${ }^{6}$ Law develops through judicial decisions in a common law jurisdiction. A court decision provides later courts deciding the same or similar issues guidance in the resolution of the case. The earlier case in that function is precedent for the subsequent. Only the decisions of higher courts in the same jurisdiction (or the Supreme Court) are binding precedent and determinative of the law applicable to subsequent cases in the same jurisdiction (and the Supreme Court in all jurisdictions).
} 
Corporate Income Taxes. Corporations in the United States are subject to the federal income tax on their worldwide incomes. ${ }^{7}$ Unlike Germany, ${ }^{8}$ for example, the United States does not separate the corporate income tax from the individual income tax. ${ }^{9}$ The Code provides general tax rules applicable to individuals, corporations and other entities. ${ }^{10}$ Within those general rules, the Code also provides some rules applicable only to individuals, ${ }^{11}$ only to corporations, ${ }^{12}$ only to partnerships and limited liability companies, ${ }^{13}$ trusts, ${ }^{14}$ etc.

Corporations are subject to a moderately progressive rate structure with rates increasing in four stages from fifteen percent of taxable income up to $\$ 50,000,25$ percent of taxable income from $\$ 50$ to 75 thousand, 34 percent of taxable income from $\$ 75$ thousand to $\$ 10$ million, and 35 percent of income in excess of $\$ 10$ million. ${ }^{15}$ In addition, the rate schedule imposes a surtax of five percent on incomes between $\$ 100$ and 335,000 that phases out the advantage of the 15 and 25 percent brackets and a surtax of three percent on incomes between $\$ 15$ and 18.33 million to phase out the advantage of the 34 percent bracket. ${ }^{16}$ As a result corporations with incomes exceeding \$18.33 million effectively pay a flat rate of 35 percent on all their income. For much of the United States' tax history, ${ }^{17}$ maximum corporate tax rates were significantly lower than individual rates.

A corporation also may be subject to an alternative minimum tax at a rate of twenty percent on the corporation's alternative minimum taxable income to the extent that amount exceeds the corporation's regular income tax. ${ }^{18}$ Alternative minimum taxable income is the taxable income of the corporation with adjustments to limit the effect of tax benefits that may be available to the corporation, ${ }^{19}$ including an adjustment for current earnings to bring the

\footnotetext{
${ }^{7}$ I.R.C. $\$ 11$ (imposing a tax on the taxable income of corporations); I.R.C. $\$ 61$ (including in the gross income of any taxpayer "all income from whatever source derived" so that the U.S. corporation is taxable on its worldwide income); I.R.C. $§ 63$ (defining taxable income as gross income less deductions).

${ }^{8}$ Körperschaftsteuergesetz [Corporation Income Tax] (KStG) in der Fassung der Bekanntmachung vom 15. Oktober 2002 (BGB1. I S. 4144), das zuletzt durch Artikel 4 des Gesetzes vom 7. Dezember 2011 (BGBl. I S. 2592) geändert worden ist (available at http://www.gesetze-im-internet.de/kstg_1977/BJNR025990976.html).

${ }^{9}$ I.R.C. $\$ 11$ is included in the Code.

${ }^{10}$ I.R.C. $\$ 61$, for example, provides that "gross income means all income from whatever source derived."

${ }^{11}$ I.R.C. $\$ 62$ (defining adjusted gross income applicable only to individuals).

${ }^{12}$ Subchapters C, I.R.C. $\$ 301$ et seq., and S, I.R.C. $\$ 1361$ et seq., of the Code, for examples. Subchapter C governs corporations generally, subchapter $\mathrm{S}$ provides special rules for corporations the shareholders of which elected tax transparency for the corporation.

${ }^{13}$ Subchapter K, I.R.C. $\$ 701$ et seq., of the Code for example.

${ }^{14}$ Subchapter J, I.R.C. $\$ 641$ et seq., of the Code for example.

15 I.R.C. $\$ 11(\mathrm{a})$.

${ }^{16} \mathrm{Id}$.

17 The Tax Reform Act of 1986, PL 99-514 (October 22, 1986) temporarily inverted the relationship between maximum corporate and individual rates and made maximum corporate rates higher than individual rates. In 2013 , the maximum individual rate is scheduled to exceed the maximum corporate rate by 4.6 percent, but corporations are taxable at regular rates on their long term capital gains while individuals are not. I.R.C. $\$ 1(\mathrm{~h})$.

${ }^{18}$ I.R.C. \$55(a) (imposing an additional tax equal to the excess of the tentative minimum tax over the regular tax). There also is a small percentage environmental tax computed in a manner similar to the alternative minimum tax under I.R.C. $\$ 59$ A.

${ }^{19}$ I.R.C. $\$ 55(\mathrm{~b})(2)$ (determining the tentative minimum tax for corporations).
} 
corporation's taxable income closer to its economic income. ${ }^{20}$ Corporations that accumulate their incomes beyond the reasonable needs of their business, rather than distributing dividends to their shareholders, also are subject to a penalty tax at a rate equal to the rate shareholders would pay on distributed dividends. ${ }^{21}$ Similarly, closely held corporations with income predominantly from passive investments like interest and dividends may be subject to a personal holding company tax, a penalty tax imposed at a rate equal to the rate shareholders would pay on distributed dividends. 22

The United States has had a corporate income tax since $1909 .{ }^{23}$ In fiscal year 2011 , the IRS processed 2,313,909 returns from corporations subject to a corporate tax, 4,545,454 returns from $\mathrm{S}$ corporations that are transparent for tax purposes, and 3,573,550 returns from partnerships. $^{24}$ In 2010, there were 23,003,656 nonfarm sole proprietorship returns filed. ${ }^{25}$ Based upon the numbers of returns, corporations and $\mathrm{S}$ corporations combined constitute more than twenty percent of business returns and more than 65 percent of business entity returns, sole proprietorships not being separate entities. Rates have fluctuated considerably over the years, but the corporate income tax consistently has produced a significant portion of federal revenue. In 2011, the corporate income tax accounted for 7.86 percent of federal revenue, the individual income tax more than 47 percent, and payroll taxes 35.5 percent. The corporate income tax produced nearly 40 percent of revenue in 1943 and dropped fairly consistently from year to year after that but is projected to increase to 13 percent in 2014 and remain in that range. The individual income tax also is projected to increase somewhat, and payroll taxes to fall slightly. ${ }^{26}$

In addition to federal income taxes, forty-five of the fifty states of the United States impose a corporate income tax on corporations that engage in business activity or have property in the state. The state rates range from a low maximum rate of 4.63 percent in Colorado to a high of 9.99 percent in Pennsylvania. Of the five states with no corporate net income, three impose a gross receipts tax, so that only Nevada and Wyoming have no corporate tax measured by income or receipts. ${ }^{27}$ Each state has independent taxing authority and the power to determine under some reasonable methodology what portion of a corporation's income is attributable to that state and subject to that state's income tax. In apportioning corporate income, each state establishes its own apportionment formula. Apportionment formulae are not uniform from state

\footnotetext{
${ }^{20}$ I.R.C. $\$ 56(c)(1)$.

${ }^{21}$ I.R.C. $\$ 531$ (imposing the accumulated earnings tax). Rarely do corporations pay an accumulated earnings tax.

${ }^{22}$ I.R.C. $\$ 541$ (imposing the personal holding company tax). Rarely do corporations pay a personal holding company tax.

${ }^{23}$ Revenue Act of 1909, ch. 6, 36 Stat. 11 (imposing a corporate income tax of 1 percent on net incomes in excess of \$5000. See, Douglas A. Kahn and Jeffrey S. Lehman, CorPORATE InCOME TAXATION 4 (St. Paul 2001). The Supreme Court upheld the tax as an excise tax on doing business in Flint v. Stone Tracy Co, 220 US 107 (1911) after rejecting an earlier combined corporate and individual income tax in Pollock v. Farmers' Loan \& Trust Co., 158 US 601 (1895) (rejecting the tax as a direct tax that had to be apportioned among the states under US Const. Art I, §9). The Sixteenth Amendment to the Constitution permitted an income tax without apportionment (1913).

${ }^{24}$ Internal Revenue Serv., Data Book 6 (2011).

${ }^{25}$ Internal Revenue Serv., Statistics of Income Bulletin, 18 (Summer 2012), Washington, D.C.

${ }^{26}$ Office of Management and Budget, Historical Tables, Table 2.1 - Receipts By Source: 1934-2017 (available at http://www.whitehouse.gov/omb/budget/Historicals).

${ }^{27}$ Tax Foundation, State Corporate Income Tax Rates as of January 1, 2012 (available at: http://taxfoundation.org/sites/taxfoundation.org/files/docs/state_corp_income_rates_2000-2012-20120216.pdf).
} 
to state, ${ }^{28}$ so that some states use a single factor of sales while other states use three factor formulae like the CCCTB Proposal. ${ }^{29}$ Except where an understanding of state taxes is critical to an understanding of corporate taxation, this report limits itself to the federal income taxation of corporations and other business entities.

Corporations and other Entities: Governing Law. The United States has neither a general federal law of corporations nor other business entities. Each state has its own statutes governing the formation and operation of various business entities formed in that state. While laws governing corporations are similar in some respects from state to state, they are not uniform. Laws governing partnerships and limited partnerships tend to be more uniform, ${ }^{30}$ but they too are not necessarily identical from state to state. On the other hand, the federal securities laws ${ }^{31}$ regulate the sale and resale of interests in state legal entities unless the offering and sale of interests takes place in a single state. Until 1977 when Wyoming enacted the first limited liability company law in the United States, ${ }^{32}$ corporations were the only operating entities that provided limited liability for all their owners and managers for acts and omissions in the ordinary course of the entity's business. While limited liability drove much of the popularity of the corporation in the United States, a maximum corporate income tax rate that was significantly lower than the maximum individual rate contributed to corporate popularity. ${ }^{33}$ Corporations were attractive to high income individuals who might grow their capital, subject to the personal holding company tax risk, ${ }^{34}$ inside a corporation at its lower corporate rate of tax. ${ }^{35}$

\footnotetext{
${ }^{28}$ While Article IV of the Multistate Tax Commission (MTC), Multistate Tax Compact (available on MTC's website at http://www.mtc.gov/About.aspx?id=86) uses an equally weighted three factor formula like that of the CCCTB Proposal. Only 18 states have adopted the Compact. MTC, Member States (available at http://www.mtc.gov/AboutStateMap.aspx). Other states use a variety of formulae, including 13 states that use only sales, some transitioning to only sales, other double or triple weighting of the sales factor. See, Federation of Tax Administrators, State Apportionment of Corporate Income, (Formulas for tax year 2012 -- as of January 1, 2012) (available at http://www.taxadmin.org/fta/rate/apport.pdf).

${ }^{29}$ European Commission, Brussels, COM(2011) 121/4, 2011/0058 (CNS)Proposal for a COUNCIL DIRECTIVE on a Common Consolidated Corporate Tax Base (CCCTB) (2011) at 14, available at http://ec.europa.eu/taxation_customs/resources/documents/taxation/company_tax/common_tax_base/com_2011_12 1_en.pdf. (CCCTB Proposal in the following). The EC describes the proposal on its website at http://ec.europa.eu/taxation_customs/taxation/company_tax/common_tax_base/index_en.htm as follows:

The European Commission on 16 March 2011 proposed a common system for calculating the tax base of businesses operating in the EU.

The proposed Common Consolidated Corporate Tax Base (CCCTB), would mean that companies would benefit from a "one-stop-shop" system for filing their tax returns and would be able to consolidate all the profits and losses they incur across the EU. Member States would maintain their full sovereign right to set their own corporate tax rate. ${ }^{30}$ Every state except Louisiana (a civil law jurisdiction) adopted the Uniform Partnership Act of 1914 with minor variations from state to state and 37 states have adopted the Revised Uniform Partnership Act of 1997. Similarly 49 states adopted the Uniform Limited Partnership Acts of 1916 and 1976, and 18 states the 2001 version. See, the website of the Uniform Law Commission at http://www.uniformlaws.org.

${ }^{31}$ The Securities Act of 1933, as amended (governing the issuance of securities involving means or instrumentalities of interstate commerce), and the Securities Exchange Act of 1934, as amended (governing the purchase and sale of securities, public securities markets, and information reporting by certain issuers of securities).

${ }^{32}$ Wyo Stat $§ 17-15-103$.

${ }^{33}$ As late as 1981, before the reduction in the maximum individual rate on investment income from 70 to 50 percent under section 1 of the Internal Revenue Code of 1954 (the 1954 Code), the maximum corporate rate of 48 percent under section 11 of the 1954 Code remained attractive.

${ }^{34}$ Supra note 22.
} 
Entity Taxation Models in the United States and their Development: Integrating Entity and Owner Taxation. The United States income tax follows the traditional "double taxation" corporate model. While certain corporations may elect tax transparency, ${ }^{36}$ corporations generally, whether they have many shareholders or a single shareholder, are subject to a corporate level income tax as fully independent taxpayers. ${ }^{37}$ In addition to entities that are corporations under state law, Treasury promulgated a list of foreign entities that are corporations for United States tax law purposes. ${ }^{38}$ With exceptions for corporate owners that may deduct all or part of the dividends they receive from other corporations in which they own shares in order to limit multiple impositions of a corporate level income tax through corporate layers,$^{39}$ the distribution of net after tax corporate income to the corporation's owners results in the distributed amounts becoming includable in the owners' incomes to be taxed there a second time. ${ }^{40}$ The corporation may not deduct the distributed amounts. This creates the customary bias toward debt capital because payments of interest on borrowed capital are deductible from the corporate level tax base. ${ }^{41}$

In addition to the traditional corporate model of taxation of certain business entities, there are no fewer than four other models of entity taxation in the United States. They include 1) tax invisibility for certain single owner entities that are tax nothings as if they were sole proprietorships when the owner is an individual and branches when the owner is an entity ${ }^{42}$ as well as grantor trusts; ${ }^{43}$ 2) fully transparent entities like partnerships, ${ }^{44}$ limited liability companies ${ }^{45}$ and real estate mortgage investment conduits; ${ }^{46} 3$ ) mostly transparent entities like $\mathrm{S}$ corporations; ${ }^{47}$ and 4) partially transparent entities under a distribution deduction model like

\footnotetext{
${ }^{35}$ Supra note 17 and accompanying text.

${ }^{36} \mathrm{~S}$ corporations, see infra note 47.

${ }^{37}$ I.R.C. $\$ 11$, supra note 15 and accompanying text.

${ }^{38}$ Treas. reg. $\$ 301.7701-2(a)(8)$ (listed alphabetically by the English language name of the country in which they are formed).

${ }^{39}$ I.R.C. $\$ 243$ (providing a 100 percent deduction for dividends received by a corporation from another corporation in which it owns more than 80 percent, 70 percent in most other instances).

${ }^{40}$ I.R.C. $\$ 301(\mathrm{c})(1)$ (including corporate dividends in a distributee’s gross income). I.R.C. $\$ 316$ (defining dividend as a distribution out of a corporation's current or accumulated earnings and profits); I.R.C. §312 (not defining earnings and profits but setting forth rules for increases and decreases in earnings and profits).

${ }^{41}$ I.R.C. $\$ 163$ (providing a deduction for interest on indebtedness).

42 Treas. reg. §301.7701-3(a), (b)(ii) (classifying eligible entities such as limited liability companies that do not elect to be corporations for tax purposes by default as disregarded entities if they have a single owner). Likewise, wholly owned, qualified subchapter S subsidiaries under I.R.C. §1361(b)(3).

${ }^{43}$ I.R.C. $\$ 671$ et seq. (setting forth rules for treating the grantor that is the person who or which funds the trust by transferring money or property to a trustee to hold and invest for the benefit of one or more beneficiaries, as the owner of the trust properties); I.R.C. $\S 678$ (treating someone other than the grantor as owner of the trust's properties because of that person's ability to vest the property of the trust in himself).

${ }^{44}$ I.R.C. $\$ 701$ et seq. (providing that partners, not the partnership are subject to tax).

45 Treas. reg. §301.7701-3(a), (b)(i) (classifying eligible entities such as limited liability companies that do not elect to be corporations for tax purposes by default as partnerships).

${ }^{46}$ I.R.C. $\$ 860$ A (REMICs not subject to tax and not corporations or partnerships; income taxed to owners of interests in the REMIC).

${ }^{47}$ I.R.C. $\$ 1361$ et seq. (providing an election for tax transparency, but I.R.C. $\$ 1374$ and $\$ 1375$ continue to impose a corporate level tax on corporations that convert from regular corporations to $\mathrm{S}$ corporations in certain instances).

See discussion of S corporation infra in text accompanying and following note 67.
} 
simple trusts, ${ }^{48}$ regulated investment companies, ${ }^{49}$ and real estate investment trusts. ${ }^{50}$ A fifth model for complex trusts that are fully taxable as they earn income but with respect to which the ultimate distributees of the income, grossed up for trust level taxes paid, get a credit for the tax paid at entity level became substantially obsolete when Congress limited the rule to foreign trusts and some domestic trusts that previously were foreign. ${ }^{51}$

Limited Liability and Defacto Tax Transparency. Under state law, corporations have separate legal personalities from their owners and corporations are separate taxable persons for federal tax purposes. ${ }^{52}$ In the absence of an S election, ${ }^{53}$ corporations are fully tax opaque. Unless a shareholder personally guarantees a corporate obligation, the state law of every state generally ${ }^{54}$ limits the liability of corporate shareholders to their contributions to the capital of the corporation. Historically, the separateness of the corporation from its owners led to double taxation, so that double taxation and limited liability became inseparable under taxation statutes.

In practice, however, double taxation and limited liability were not inseparable. In closely-held corporations with limited, often single family, ownership, the owners eliminated double taxation by withdrawing most or all corporate profit through deductible salaries and benefits. ${ }^{55}$ Often the IRS sought to disallow the deduction for compensation that it deemed excessive and recharacterize the purported salary amounts as dividends or other nondeductible expenditures. The IRS's success in litigating that issue became increasingly infrequent as taxpayers planned more extensively for that challenge and developed strong cases for the reasonableness of compensation. ${ }^{56}$ This defacto tax transparency only operated on the income side. Corporations experiencing losses could not pass those losses through to their shareholders although a special rule for small corporations enabled shareholders to claim ordinary loss on the sales of their shares ${ }^{57}$ rather than disfavored capital loss. ${ }^{58}$

\footnotetext{
${ }^{48}$ I.R.C. $\$ 651$ (allowing a deduction from the trust's income for distributions to beneficiaries that the trust instrument requires, thereby eliminating trust income where the trust must distribute all its income).

${ }^{49}$ I.R.C. $\$ 852(\mathrm{~b})(2)(\mathrm{D})$ (allowing a deduction for dividends paid but no loss transparency).

${ }^{50}$ I.R.C. $\$ 857$ (b)(2)(B) (allowing a deduction for dividends paid but no loss transparency).

${ }^{51}$ I.R.C. $\$ 667$ (b) (providing the effect of a credit to the beneficiaries receiving accumulation distributions from a trust. Compare, the advance corporate tax (imputation system) that was popular in the European Union before the Manninen and ACT Test Claimants GLO decisions of the ECJ.) The Taxpayer Relief Act of 1997, PL 105-34, added I.R.C. $\$ 665(\mathrm{c})$ limiting the accumulation distribution rules to foreign trusts.

${ }_{52}^{52}$ I.R.C. $\$ 11$ (imposing a tax on the income of a corporation), see supra note 15.

${ }_{54}^{53}$ See discussion infra note 67

${ }^{54}$ Shareholders or officers and directors of a corporation may lose limited liability if they fail to respect the state law formalities of operation and documentation under a theory of piercing the corporate, dominate and control the corporation in a manner such that the shareholders or officers and directors of the corporation disregard the separateness of the corporation, and shareholders remain liable to the extent of capital contributions they commit to make but have not made.

${ }^{55}$ I.R.C. $\$ 162$ (allowing a deduction for ordinary and necessary business expenses, including reasonable compensation).

${ }^{56}$ Boris Bittker and James Eustice, FEDERAL INCOME TAXATION OF CORPORATIONS AND SHAREHOLDERS פ[8.05[3] (Valhalla 2000).

${ }^{57}$ I.R.C. $\$ 1244$ (allowing as much as $\$ 100,000$ ordinary loss on the sale of original issue shares of small business corporations).

${ }^{58}$ For individual taxpayers, capital losses are deductible only to the extent of capital gains plus $\$ 3000$ per year. Taxpayers may carry unused capital losses forward indefinitely. For corporate taxpayers, capital losses are
} 
Tax Transparency and Unlimited Liability. Unlike corporations that are separate from their owners, partnerships do not separate quite so readily from their owners. Partnerships did not and do not shield their owners from the entity's obligations. Under state law, all the partners in partnerships are personally liable either jointly or jointly and severally ${ }^{59}$ for the partnership's debts, and limited partnerships must have at least one general partner who or which is personally liable for the partnership's debts. ${ }^{60}$ Since the owners bear the ultimate risk of loss from partnerships' activities, partnerships, both general and limited, were and continue to be fully tax transparent. ${ }^{61}$ Each partner includes the partner's distributive share of the partnership's income, loss, deductions, and credits when computing the partner's separate taxable income. ${ }^{62}$ Some partnership items are part of a partnership level computation of income and loss, but other partnership items are separately stated because their characteristics cause them to have differing impacts in different partners' tax computations. ${ }^{63}$ With respect to both the partnership level computation and the separately stated items, the partner includes the partner's share as if the partner received the item from the same source and in the same manner as the partnership received it. $^{64}$

Tax Transparency and Limited Liability. The requirement of unlimited liability as a condition of tax transparency began to weaken in the United States in the 1950s and ultimately

deductible to the extent of capital gains only and may be carried forward for a limited period of years. I.R.C. $\S \S 1211,1212$.

${ }^{59}$ Section 15 of the Uniform Partnership Act of 1914, as still in effect in some states, (available at http://www.uniformlaws.org/Act.aspx?title=Partnership\%20Act\%20\%281914\%29) provided that partners were jointly liable for contractual obligations of the partnership but jointly and severally liable for tort (personal injury) obligations. Section 306 of the Uniform Partnership Act of 1997 (available at

http://www.uniformlaws.org/shared/docs/partnership/upa_final_97.pdf) similarly makes partners jointly and severally liable for obligations of the partnership. "Several" liability means that each partner is fully liable for 100 percent of the partnership's debts so that a creditor may proceed against any partner for the full debt. Partners who have to pay a full debt may have a right to demand contributions from the other partners, but that right of contribution does not limit the creditor's right to collect from each partner. "Joint" liability requires a creditor to proceed against all the partners together because each partner is liable only for his or her share of the partnership's debt.

${ }^{60}$ Section 1 of the Uniform Limited Partnership Act of 1916 (adopted in almost all states and still in effect in some) (available at http://www.uniformlaws.org/shared/docs/limited\%20partnership/ulpa1916.pdf) required a limited partnership to have one or more general partners and provided that limited partners were not "bound by the obligations of the partnership."

${ }^{61}$ I.R.C. $\$ 701$ (drawing no distinction between general and limited partnerships, partners, not partnerships, subject to tax). Subchapter K that includes I.R.C. $\$ 701$ et seq. became part of the tax law in the major tax law revision that produced the 1954 Code. The 1954 Code became the current Code in 1986 without any significant renumbering or restructuring of basic rules. Before 1954, there was inadequate statutory treatment of the taxation of partnerships so that considerable uncertainty and unpredictability of outcome existed for partnership taxation. Joint Committee on Internal Revenue Taxation and the Treasury Department, INTERNAL REVENUE CODE OF 1954: COMPARISON OF THE Principal Changes MAde IN THE 1939 CODE By H.R. 8300 AFTER ACTION By House, SENATE, AND CONFERENCE (August 13, 1954).

${ }^{62}$ I.R.C. $\$ 702(a)$ (inclusion of partnership items in the partners' incomes).

${ }^{63} I d$. Capital gains and losses remain separately stated, for example, because they impact partners' tax computations in differing ways. I.R.C. \$702(a)(1), (2).

${ }^{64}$ I.R.C. $\$ 702$ (b) (preserving source and manner of partnership items). 
disappeared as states enacted limited liability company legislation beginning in $1977 .{ }^{65}$ Doubts lingered within the tax community that unlimited liability still might be critical to certainty of tax transparency until 1996 when Treasury's replaced the entity classification regulation with the socalled check-the-box classification rule. The new entity classification rule made tax transparency the default classification for limited liability companies and limited partnerships and dispelled all such doubts. ${ }^{66}$

Corporations under Subchapter S. In 1958, Congress expressly delinked limited liability from double taxation for some corporations when it added a new subchapter $\mathrm{S}$ to the Code. ${ }^{67}$ Under subchapter $\mathrm{S}$ some small businesses operating in corporate form could elect a form of tax transparency. Congress intended the legislation to stimulate small business by diminishing the corporate tax disadvantage relative to the partnership form. Eligibility for the subchapter $\mathrm{S}$ election required that the corporation be an active, operating, as opposed to investment, business. ${ }^{68}$ In addition, a subchapter $S$ corporation could have no more than ten shareholders who had to be individuals, but not non-resident aliens, ${ }^{69}$ or estates of qualifying individuals. The corporation could not issue more than a single class of stock. ${ }^{70}$ Unlike the defacto tax transparency described above, ${ }^{71}$ subchapter $\mathrm{S}$ corporations passed both income ${ }^{72}$ and losses $^{73}$ through to their shareholders.

Subsequent changes to the provisions governing $\mathrm{S}$ corporations have eliminated the requirement of an active business, permitted certain trusts and exempt organizations to be shareholders, ${ }^{74}$ allowed the corporation to issue both voting and nonvoting shares, ${ }^{75}$ and expanded the number of shareholders nominally to one hundred ${ }^{76}$ but in counting the numbers included all individuals with a common ancestor as far back as six generations as a single shareholder, so the number of shareholders may exceed one hundred by a considerable amount. ${ }^{77}$ Tax transparency is now direct in the same manner as a partnership so that each shareholder includes her proportional share of each tax item of the corporation as if the shareholder received

\footnotetext{
${ }^{65}$ Supra note 32 and accompanying text.

66 Treas. reg. $\$ 301.7701-3$ (regulation amendment of 12/17/96) (classifying entities with two or more owners that are not included in corporate entity list in treas. reg. $\$ 301.7701-2$, including partnerships, limited partnerships, limited liability partnerships, limited liability companies, and a variety of foreign entities, as eligible entities treated as partnerships unless they elect to be associations taxable as corporations for tax purposes). See further discussion, infra in text accompanying note 90.

${ }^{67}$ The Small Business Tax Revision Act of 1958, PL 85-866 (September 2, 1958) added subchapter S to the 1954 Code. Such corporations are now referred to as S corporations under a definition in I.R.C. $\$ 1361(a)(1)$.

${ }^{68}$ Section 1372(e)(5) of the 1954 Code (terminating the election if more than 20 percent of the corporation's gross receipts were passive investment income).

${ }^{69}$ Section 1371(a)(3) of the 1954 Code and I.R.C. $\$ 1361(b)(1)(C)$ prohibit ownership by nonresident aliens in order to assure imposition of an income tax in the U.S. Both U.S. citizens, whether resident in the U.S or not, and resident aliens are taxable in the U.S. on their income from all sources worldwide.

${ }^{70}$ Section 1371(a)(4) of the 1954 Code (single class of stock requirement for qualification).

${ }^{71}$ Supra note 52 and accompanying text.

${ }^{72}$ Section 1373 of the 1954 Code.

${ }^{73}$ Section 1374 of the 1954 Code.

${ }^{74}$ I.R.C. $§ 1362(c)(2),(6)$ (allowing certain trusts and exempt organizations as shareholders respectively).

${ }^{75}$ I.R.C. $\$ 1362$ (c)(4) (allowing differences in voting rights).

${ }^{76}$ I.R.C. $\$ 1362$ (b)(1)(A) (limiting the number of shareholders to 100).

${ }^{77}$ I.R.C. $\$ 1362$ (c)(1) (counting individuals with a common ancestor as one shareholder).
} 
the item directly from its source. ${ }^{78}$ Nevertheless, S corporations that previously were nonelecting corporations continue to be taxable at corporate rates on pre-election increases in value when they sell the appreciated assets ${ }^{79}$ and may be taxable on passive income if the more than twenty-five percent of the corporation's gross receipts are passive investment income. ${ }^{80}$

Electing the Double Taxation Model to Capture Corporate Tax Benefits. Professionals such as physicians, lawyers, dentists, and accountants may not limit their liability for their own malpractice. State laws prohibited professionals working in groups from forming business corporations. When tax benefits for certain employee plans such as retirement plans became available for corporations, but not for partnerships and sole proprietorships, ${ }^{81}$ professional service businesses sought structures that would enable them to claim they were associations taxable as corporations in order to capture those benefits. ${ }^{82}$ State legislatures enacted professional corporation and association statutes to facilitate access for their professional residents to corporate tax benefits. ${ }^{83}$ Under a regulation that identified four characteristics of corporations that caused them to differ from partnerships: i) perpetual life, ii) centralized management, iii) limited liability, and iv) free transferability of interests, ${ }^{84}$ the government sought to classify professional associations as partnerships for tax purposes rather than corporations. $^{85}$ After losing consistently in litigation on that issue, the IRS accepted the taxpayers' corporate classifications under state law. ${ }^{86}$ In most instances, those professional service corporations gained the corporate tax benefits unavailable to partnerships but paid little or no tax at corporate level because they drew off the remaining corporate income as salaries and bonuses. ${ }^{87}$ Since the professional service corporation's income is attributable solely to the services of its employees and owner employees and not to any investment of capital, the government generally has not been successful in arguing that compensation is unreasonable and nondeductible.

Tax Shelter Limited Partnerships. The government used the same regulation, albeit also unsuccessfully for the most part, to classify tax shelter limited partnerships as associations

\footnotetext{
${ }^{78}$ I.R.C. $\$ 1366$ (inclusion of S corporation items).

${ }^{79}$ I.R.C. $\$ 1374$ (tax on built-in gain). The tax on built-in gain ceases to apply to the corporation ten years following its S election. I.R.C. $\$ 1374(d)(7)$.

${ }^{80}$ I.R.C. $\$ 1375$ (tax on passive investment income).

${ }^{81}$ Most disparities in tax treatment between corporations and other forms of business no long exist.

${ }^{82}$ US v. Kintner, 216 F.2d 418 ( $9^{\text {th }}$ Cir. 1954) (holding a physician practice association to be taxable as a corporation and eligible for corporate employee benefit plans).

${ }^{83}$ Bittker and Eustice, FEDERAL INCOME TAXATION OF CORPORATIONS AND SHAREHOLDERS, supra note 56, at $\$[2.06$ (Valhalla 2000).

${ }^{84}$ Treas. reg. \$301.7701-2(a) (adopted 11/15/60) (identifying six characteristics of corporations disregarding two in distinguishing corporations from partnerships, associates and a purpose to carry on a business for profit, because partnerships and corporations have those in common).

85 Treas. reg. \$301.7701-2(h) (amended 2/2/65 clarifying treatment of professional services associations) (classifying most professional service corporations as partnerships because of their resemblance to partnerships rather than corporations).

${ }^{86}$ Rev. Rul. 70-101, 1970-1 CB 278 (announcing discontinuance of litigation on the classification issue and listing states with compliant professional service corporation statutes).

${ }^{87}$ See text accompanying note 55 supra.
} 
taxable as corporations. ${ }^{88}$ In order to limit liability, some limited partnerships had only a corporate general partner. Although the corporate partner itself had unlimited liability for the partnership's obligations, the corporation's owners had limited liability as did the limited partners who were the investors and owned the bulk of the interests in the partnership's income and losses. As generally was the case, the corporate general partner had few, if any, assets, so that as a practical matter the limited partnership probably had technical unlimited liability but nominal limited liability, one of the four corporate characteristics that distinguished corporations from partnerships. And the limited partnership had centralized management, another of the corporate characteristics, in that the limited partners could not take part in management without jeopardizing their limited liability.

Nevertheless, the limited partnership restricted transfers of interest by requiring the consent of the general partner or all the partners, so that free transferability of interests was lacking. The limited partnership also avoided the perpetual life characteristic by stating its term, often forty years or more, in its required state law filing documentation. Thus, the limited partnership lacked at least two of the four corporate characteristics, a tie, and that tie allowed the courts to respect the limited partnership's chosen classification. If the government had been successful in classifying the limited partnership as an association taxable as a corporation under the regulation, the partnership would have been subject to double taxation but, more importantly, would not pass its losses through to its limited partner investors who were seeking losses to shelter their income from other sources from taxation. ${ }^{89}$

Transparency and the Check the Box Regulation. Despite the government's lack of success in classifying limited partnerships as corporations, practitioners remained concerned about reclassification of limited partnerships and later limited liability companies as associations taxable as corporations until 1996 when Treasury replaced the classification regulation for business entities with the "check-the-box" regulation. ${ }^{90}$ Under that regulation, domestic entities that the regulation does not classify as corporations or associations taxable as corporations, including limited partnerships and limited liability companies, are tax transparent partnerships unless they elect to be associations taxable as corporations for tax purposes. ${ }^{91}$

Public Trading, not Limited Liability, as the Limitation on Tax Transparency. Publicly traded businesses tended to operate in corporate form and issue shares that they list on one of the stock exchanges or in the over the counter market quotation systems such as NASDAQ. ${ }^{92}$ For a short period of time in the early 1980s, some publicly traded operating corporations converted to limited partnerships. ${ }^{93}$ They adopted the tax shelter limited partnership model, that is, they vested management in a corporation that served as the general partner of limited partnership and substituted publicly traded limited partnership interests for shares. Changes in limited

\footnotetext{
${ }^{88}$ Supra note 84 .

${ }^{89}$ See, Henry Ordower, The Culture of Tax Avoidance, 55 SAINT LOUIS U L J 47, 58-66 (2010) (discussing syndicated, limited partnership tax shelters).

${ }^{90}$ Treas. reg. $\$ 301.7701-3$, supra note 66, (elective entity classification with partnership as default classification).

91 Treas. reg. \$301.7701-3(c) (allowing eligible entities to elect a different classification from the default classification).

92 The National Association of Securities Dealers Automated Quotation system.

${ }^{93}$ See, generally, William S. McKee, Master Limited Partnerships, 45 NYU InST. ON FED. TAXATION, ch. 23 (1987).
} 
partnership law allowed limited partners to assume a greater role in the partnership, including specific voting rights, without jeopardizing their limited liability. ${ }^{94}$ As limited partnerships they were tax transparent. Each limited partner received a share of the corporate tax items as if the limited partner had received them directly from their source. In order to prevent the disincorporation of America and the destruction of the corporate tax base, Congress classified publicly traded partnerships as corporations for tax purposes. ${ }^{95}$ Exceptions to the classification as corporations existed for publicly traded partnerships that received at least ninety percent of their gross income from passive investment sources. ${ }^{96}$ For business entities engaged in the active conduct of business, public trading supplanted limited liability as the factor that precludes tax transparency in the United States.

Investment Entities and Tax Transparency. The active business, passive investment distinction that manifests itself in the publicly traded partnership statute, ${ }^{97}$ rather than limitations on liability, helps to explain many of the other entity types that are partially or fully transparent.

Trusts. Trusts do not engage in the active conduct of business. ${ }^{98}$ Rather trusts enable the legal owner of property, the trustee, to manage and invest property for the benefit of the beneficial owner or owners of that property. When the trustee has discretion to accumulate income rather than distributing it currently to the beneficiaries, ${ }^{99}$ the trust becomes taxable on the accumulation lest the income not become taxable when accrued or received. ${ }^{100}$ Historically, trusts could not have perpetual life, ${ }^{101}$ so that ultimately they had to distribute their accumulated income to the trust beneficiaries. Accordingly, taxation of the trust itself needed only to be a temporary tax collection with adjustment to follow on final reckoning through an imputation mechanism. ${ }^{102}$ In response to perpetual trusts, ${ }^{103}$ and in light of the compression of the marginal income tax brackets for trusts that resulted in trust income becoming subject to tax at a virtually flat rate equal to the maximum individual rate, ${ }^{104}$ the imputation system became obsolete. Since the imputation system earlier prevented taxpayers from using trusts to capture additional low rate brackets on some of their income, the system became unnecessary and Congress repealed it for

\footnotetext{
${ }^{94}$ Article 3 of the Uniform Limited Partnership Act of 1976, and as amended in 1985 (available at http://www.uniformlaws.org/shared/docs/limited\%20partnership/ulpa7685.pdf) (protecting limited liability and specifying partnership activities that did not jeopardize limited liability).

95 The Revenue Act of 1987, PL 100-203 added I.R.C. $\$ 7704$ (classifying publicly traded partnerships as corporations).

${ }^{96}$ I.R.C. $\$ 7704$ (c) (excepting partnerships with 90 percent passive income from the classification as corporations).

${ }^{97} \mathrm{Id}$.

${ }^{98}$ Exceptions exist for specialized trusts like Massachusetts business trusts.

${ }^{99}$ I.R.C. $\$ \$ 651,661$ (allowing a deduction for trust distributions to beneficiaries).

${ }^{100}$ I.R.C. $\$ 1(\mathrm{e})$ (imposing a tax on the taxable income of a trust); I.R.C. $\$ 641$ (imposing the tax under I.R.C. $\$ 1(e)$ ).

${ }^{101}$ The rule against perpetuities required that a trust terminate and distribute its assets, including accumulated income, no later than a period measured by lives in being plus 21 years. States increasingly began to abolish the rule against perpetuities after 1986 (partially in connection with an exemption from the generation skipping tax) to allow so-called dynastic trusts.

${ }^{102}$ I.R.C. $\$ \$ 666,667$ (grossing up and including accumulation distributions in a beneficiary’s income). Compression of the trust rate brackets under I.R.C. \$1(e) in 1986 eliminated any earlier tax advantage there may have been to accumulate income in a trust rather than distributing it to the trust's beneficiaries so that accumulations currently are almost exclusively for non-tax reasons.

103 Supra note 101.

${ }^{104}$ I.R.C. $\$ 1$ (e) (imposing tax on trust income at compressed marginal rates).
} 
domestic trusts. ${ }^{105}$ Taxation of trusts and their beneficiaries is complex and relates only very tangentially to the corporate income tax.

Partial Tax Transparency and Pooled Investment Entities. Following the active/passive distinction and in order to facilitate the free choice of entity for pooled passive investments without concern about federal income taxes, mutual funds (RICs) ${ }^{106}$ and real estate investment trusts (REITs) ${ }^{107}$ are partially tax transparent. So long as they distribute at least ninety percent of their income to their shareholders annually ${ }^{108}$ and continue to meet the qualifications for their classification as RICs and REITs respectively, RICs and REITs may deduct the amount of the distributions. As a result of the deduction, they are taxable at entity level only on their undistributed income. ${ }^{109}$ RICs and REITs may not pass losses through to their shareholders. Other pooled investment entities tend to operate in limited partnership or limited liability company form so that they are fully tax transparent. ${ }^{110}$ While the RIC and REIT provisions of the Code predate the publicly traded partnership provisions, they are consistent with the active/passive distinction that underlies the publicly traded partnership rules.

\section{Personal Holding Company Penalty Tax Compels Tax Transparency for}

Investment. Traditionally, people operating active businesses chose corporate form to limit their liability. Partnerships for investments tended to be acceptable, and the personal holding company tax ${ }^{111}$ compelled direct ownership or tax transparent entity ownership of investments. The personal holding company tax enforces double taxation by imposing a penalty tax equal to the maximum tax that would be imposed on individual shareholders if the corporation distributed all its income to the shareholders as dividends. Personal holding companies are closely held corporations $^{112}$ the income of which primarily is from passive investments. ${ }^{113}$ Absent the ability to accumulate income for corporate growth with only a single, corporate level of tax, the tax opaque corporate model makes little sense. In addition, investors did not need limited liability because passive investments are unlikely to result in tort liability and the investors could insure at a nominal cost against whatever tort liability might arise. Personal liability in contract for investment debts is substantially unavoidable. Institutional lenders require personal guarantees for investment borrowing, with the possible exception of traditional nonrecourse financing for real property. Investment businesses do not have suppliers of goods and services that operating businesses have who might supply without a personal guarantee.

\footnotetext{
${ }^{105}$ I.R.C. $\$ 665(\mathrm{c})$, supra note 51.

${ }^{106}$ I.R.C. $\$ 851$ (regulated investment companies).

${ }^{107}$ I.R.C. $\$ 856$ (real estate investment trusts).

${ }^{108}$ As a practical matter, most RICs and REITs distribute very little of their income to their shareholders. Instead when shareholders invest in the RIC or REIT, they elect to reinvest dividends automatically. The RIC or REIT declares the necessary dividend, but owing to the elections to reinvest, they retain most of the declared dividend and increase the share balance of the shareholders who have elected reinvestment of dividends.

${ }^{109}$ I.R.C. \$852(b) (RICs), 857(b) (REITs).

${ }^{110}$ Customarily, hedge funds, private equity funds, and commodities pools all operate as partnerships. See, generally, Henry Ordower, Demystifying Hedge Funds: A Design Primer, 7 U. CAL. DAVIS BusINESS L. J. 323 (2007) and The Regulation of Private Equity, Hedge Funds and State Funds, United States National Report, 58 AMERICAN JOURNAL OF COMPARATIVE LAW - SUPPLEMENT 1 295-321 (2010).

${ }^{111}$ I.R.C. $\$ 541$ et seq, supra note 22 and accompanying text.

112 I.R.C. $\$ 542$ (defining personal holding company).

${ }^{113}$ I.R.C. $\$ 543$ (defining personal holding company income).
} 
Why Choose Double Taxation When Transparency is Available? Despite limited liability no longer being a barrier to tax transparency ${ }^{114}$ and the absence of a tax rate advantage to accumulating income within a corporation, ${ }^{115}$ corporations remain popular for new business formations alongside limited liability companies. Non-tax reasons for that popularity include the lengthy history of the corporate form that yields greater legal certainty concerning corporate structures and operations than is present for newer limited liability companies. In addition, as corporations grow and plan for public offerings of their shares, the regulatory agencies, especially the Securities and Exchange Commission and self-regulatory agencies like the stock exchanges, are far less welcoming of limited liability companies than they are of corporations.

Among the most promising exit strategies for many investors in new businesses is a sale of the business as a whole. Operating in corporate form broadens the appeal of the businesses for acquisition because larger, publicly traded corporations may use their own stock for the acquisition. Under the corporate reorganization provisions of the Code, ${ }^{116}$ a corporation may acquire another corporation without regard to relative sizes of the corporations and without the acquisition becoming a taxable event. Neither the corporations nor their owners need recognize income or gain on the acquisition. The target corporation's shareholders may sell some or all the shares of the acquiring corporation as they wish ${ }^{117}$ and recognize gain only then. ${ }^{118}$ These tax deferred acquisitions generally are not available if the target is a limited liability company unless the acquiring entity also is a limited liability company or a partnership. Since the likely set of potential buyers may be publicly traded operating businesses, they will be corporations for tax purposes without regard to their legal form. ${ }^{119}$ For high technology and entertainment start-up businesses, for example, the field of potential acquirers is the large, publicly traded corporations in those industries.

For certain types of investors, the corporate form of the entity into which they invest may be critical. Tax exempt organizations, including pension plans and public charities, might become subject to the unrelated business income tax if the operating entity were a partnership. ${ }^{120}$ Less important perhaps to the selection of corporate form is the dividends received deduction available to corporations receiving dividends from corporations in which they own shares. ${ }^{121}$ Corporations may own interests in partnerships and limited liability companies and include their respective shares of the entity's tax items in the same manner as any other owner.

\footnotetext{
${ }^{114}$ See discussion of the "check-the-box" entity classification rules under treas. reg. $\$ 301.7701$-, supra note 90 and accompanying text.

${ }^{115}$ See discussion of the historical corporate/individual rate differential, supra note 17.

${ }^{116}$ I.R.C. $\S 368$ (a) (defining reorganization); I.R.C. $\$ \$ 354,356,361$ (providing operating rules for tax-deferred reorganizations).

${ }^{117}$ Under the securities laws, the target's shareholder may be subject to a lock-up period during which they may not sell any of the acquiring corporation's shares.

${ }^{118}$ Under I.R.C. \$358, the target corporation’s shareholders transfer their tax bases in their shares of the target corporation to their shares in the acquiring corporation so that the reorganization rules defer the recognition of gain but do not eliminate it permanently.

${ }^{119}$ I.R.C. $\$ 7704$ (publicly traded partnerships), supra note 95 and accompanying text.

${ }^{120}$ See discussion of the unrelated business income tax infra in text accompanying note 130.

${ }^{121}$ I.R.C. $\$ 243$ (allowing a dividends received deduction to corporate shareholders), supra note 39.
} 
Charitable and other Tax Exempt Organizations. Many organizations, some trusts, some corporations, and some associations are exempt from the federal income tax. ${ }^{122}$ Churches and charities are among those tax exempt organizations, ${ }^{123}$ as are employee retirement plans. ${ }^{124}$ Organizations that are within the church, charity, educational, and similar functional categories also may receive contributions, the amounts of which the donors, subject to income percentage and other limitations, may deduct in computing their taxable incomes. ${ }^{125}$ Since the United States does not have a federal value added tax, exemptions from state sales taxes and property taxes depend upon state law and vary widely from state to state. Nevertheless, the property and purchases of goods and services to support the exempt function of the organization generally are exempt from both property and sales taxes.

Churches, charitable, and educational organizations lose their exemptions from taxation and their ability to receive tax deductible contributions if any part of their earning inures to private benefit $^{126}$ or they engage in any substantial manner in lobbying for legislation or supporting a political candidate in an election. ${ }^{127}$ If an organization loses its tax exempt status, it becomes taxable on its income as a trust if it is a trust ${ }^{128}$ and otherwise as a corporation. ${ }^{129}$

In addition, all tax exempt organizations, but not governmental units other than state owned colleges and universities, ${ }^{130}$ are subject to the unrelated business income tax. ${ }^{131}$ The exempt organization must compute and pay tax at trust rates if it is a trust ${ }^{132}$ and corporate rates if it is a corporation or another type of organization on its unrelated business taxable income. ${ }^{133}$ Unrelated business taxable income includes the net income from any unrelated business the organization regularly carries on ${ }^{134}$ and investment income the acquisition and holding of which the organization finances with borrowed funds. ${ }^{135}$ A business is unrelated unless it furthers, other than through financial support, the specific exempt function of the organization. ${ }^{136}$ For

\footnotetext{
${ }^{122}$ I.R.C. \$501(a) (exempting organizations described in the 29 classes listed in I.R.C. \$501(c); religious and apostolic organization under I.R.C. §501(d); and qualified pension and profit sharing plans described in I.R.C. $\S 401)$. In addition, state and local governments are exempt under I.R.C. $§ 115$.

${ }^{123}$ I.R.C. $\$ 501(\mathrm{c})(3)$ (including corporations and other organizations organized exclusively for religious, charitable, ..., educational, ... purposes).

${ }^{124}$ I.R.C. $\$ 401$ (describing qualified retirement plans, etc.).

${ }^{125}$ I.R.C. $\$ 170$ (allowing a charitable contribution deduction for gifts to governmental units, churches and charitable organizations subject to limitations under I.R.C. $\$ 170(b))$.

${ }^{126}$ I.R.C. $\$ 501(\mathrm{c})(3)$ (prohibiting private inurement). The IRS has raised the private inurement issue from time to time with the salaries and bonuses paid to employees of some organizations - generally unsuccessfully.

${ }^{127}$ Id. (prohibiting political activity, subject to specific lobbying limitations under I.R.C. $\$ 501(\mathrm{~h})$ ). The IRS rarely challenges churches on the political intervention issue, even where they invite one candidate to speak from the pulpit but not the opposing candidate.

${ }^{128}$ I.R.C. $\$ 1(\mathrm{e})$ (imposing tax on a trust).

${ }^{129}$ I.R.C. $\$ 11$ (imposing tax on a corporation).

${ }^{130}$ I.R.C. $\$ 511(\mathrm{a})(2)$.

${ }^{131}$ I.R.C. $\$ 511$ (imposing the unrelated business income tax on otherwise tax exempt entities).

${ }^{132}$ I.R.C. $\$ 511$ (b) (imposing tax under I.R.C. $\$ 1(\mathrm{e})$ ).

${ }^{133}$ I.R.C. $\$ 511(\mathrm{a})(1)$ (imposing tax under I.R.C. \$11 on corporations and other entities).

${ }^{134}$ I.R.C. \$512(a)(1) (defining unrelated business taxable income).

${ }^{135}$ I.R.C. $\$ 514$ (a) (defining debt financed income as unrelated business taxable income).

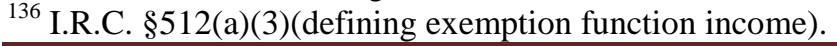


example, tuition income to a university would be exempt function income while income from the operation of a spaghetti factory would be unrelated business taxable income. ${ }^{137}$

Exempt organizations especially pension plans tend not to invest in partnership taxed pooled investment vehicles because they often employ borrowing leverage that would cause part of the income to become subject to the unrelated business income tax. Hedge and private equity funds often maintain a corporate feeder fund, frequently offshore, into which the exempt organizations invest. The corporate feeder traps the income from the investment partnership and distributes it to the exempt investors as dividends that are not unrelated business taxable income. $^{138}$

Foreign Corporations and other Foreign Entities. United States tax law taxes foreign corporations on their income that is effectively connected with their conduct of a United States trade or business in the same manner as it taxes United States corporations. ${ }^{139}$ That effectively connected income would include the foreign corporation's share of the income of a tax transparent entity engaged in a United States trade or business. ${ }^{140}$ Subject to treaty limitations, foreign corporations also are taxable through a withholding tax on various types of periodic income from United States sources, but not capital gains, at a default rate of thirty percent. ${ }^{141}$ Foreign entities, other than the entities set forth in the list in the regulations as corporations, ${ }^{142}$ are partnerships ${ }^{143}$ and tax transparent if their members do not have limited liability and associations taxable as corporations ${ }^{144}$ unless they elect tax transparency on their income from United States sources. $^{145}$

\footnotetext{
137 The story goes that Congress enacted the unrelated business income tax when New York University acquired as a gift the controlling interest in a major pasta manufacturer.

${ }^{138}$ See, generally, Henry Ordower, Demystifying Hedge Funds, supra note 110 at 361.

${ }^{139}$ I.R.C. $\$ 882$ (taxing U.S. trade or business income of a foreign corporation).

${ }^{140}$ I.R.C. $\$ 702$ (b) (preserving manner and source of a partner's share of the partnership's income).

${ }^{141}$ I.R.C. $\$ 881$ (imposing a withholding tax on periodic income, including interest, dividends and royalties).

142 Treas. reg. \$301.7701-2(b)(8) (listing foreign entities that are corporations for U.S. tax purposes).

${ }^{143}$ (defining other business entities as partnerships if they have two or more owners or branches or sole proprietorships if they have only one owner).

144 Treas. reg. $\$ 301.7701-3(b)(2)$ (classifying foreign eligible entities by liability).

145 Treas. reg. $\$ 301.7701-3$ (c) (allowing eligible entities to elect a different tax classification).
} 